\title{
X-linked Nephrogenic Diabetes Insipidus Mutations in North America and the Hopewell Hypothesis
}

\author{
Daniel G. Bichet, * Marie-Françoise Arthus, * Michèle Lonergan, * Geoffrey N. Hendy, \\ Ann Josée Paradis," T. Mary Fujiwara, ${ }^{* 1 * *}$ Kenneth Morgan, \\ Walter Rosenthal," Aarati Didwania," Anaid Antaramian," and Mariel Birnbaumer"s \\ *Unité de Recherche Clinique, Centre de Recherche et Service de Néphrologie, Hôpital du Sacré-Coeur, Département de Médecine, \\ Université de Montréal, Montréal, Québec, Canada H4J 1C5; Departments of ${ }^{\ddagger}$ Medicine, ${ }^{\S}$ Physiology, "Epidemiology and Biostatistics, \\ 'Pediatrics, and **Centre for Human Genetics, McGill University, Montreal, Quebec, Canada H3A 1A1; \\ \#Division of Nephrology, Department of Medicine, The University of Utah, Salt Lake City, Utah 84112; \\ and ${ }^{\$}$ Department of Cell Biology, Baylor College of Medicine, Houston, Texas 77030
}

\begin{abstract}
In X-linked nephrogenic diabetes insipidus (NDI) the urine of male patients is not concentrated after the administration of the antidiuretic hormone arginine-vasopressin. This disease is due to mutations in the $V_{2}$ receptor gene that maps to chromosome region Xq28. In 1969, Bode and Crawford suggested that most NDI patients in North America shared common ancestors of Ulster Scot immigrants who arrived in Halifax in 1761 on the ship Hopewell. A link between this family and a large Utah kindred was also suggested. DNA was obtained from 17 affected male patients from the "Hopewell" kindred and from four additional families from Nova Scotia and New Brunswick who shared the same Xq28 NDI haplotype. The Utah kindred and two families $\left(Q_{2}, Q_{3}\right)$ from $Q u e b e c$ were also studied. The "Hopewell" mutation, W71X, is a single base substitution $(G \rightarrow A)$ that changes codon 71 from TGG (tryptophan) to TGA (stop). The W71X mutation was found in affected members of the Hopewell and of the four satellite families. The W71X mutation is the cause of X-linked NDI for the largest number of related male patients living in North America. Other families (Utah, $Q_{2}$ and $Q_{3}$ ) that are historically and ethnically unrelated bear other mutations in the $V_{2}$ receptor gene. ( $J$. Clin. Invest. 1993. 92:1262-1268.) Key words: deoxyribonucleic acid mutational analysis • vasopressins • heterozygote detection • G-proteins • vasopressin receptors
\end{abstract}

\section{Introduction}

X-linked nephrogenic diabetes insipidus (NDI) ${ }^{1}$, designated 304800 in McKusick's catalog in Mendelian Inheritance in Man (1) is a rare disease in Europe $(2,3)$ and North America (4-6) in which the urine of affected patients does not concentrate after the administration of the antidiuretic hormone argi-

Address correspondence to Dr. Daniel G. Bichet, Centre de Recherche, Hôpital du Sacré-Coeur de Montréal, 5400 Boulevard Gouin Ouest, Montréal, Québec, Canada H4J 1 C5. 1993.

Received for publication 8 March 1993 and in revised form 21 April

1. Abbreviations used in this paper: ASO, allele specific oligonucleotide analysis; NDI, nephrogenic diabetes insipidus.

J. Clin. Invest.

(C) The American Society for Clinical Investigation, Inc.

0021-9738/93/09/1262/07 \$2.00

Volume 92, September 1993, 1262-1268 nine vasopressin (7). Bode and Crawford (4) studied a large extended kindred with NDI and described the history and folklore of "the water drinkers' curse." On the basis of their genealogical reconstructions, they proposed "the Hopewell hypothesis," that is, most cases of NDI in North America could be traced to descendants of Ulster Scots who arrived in Nova Scotia in 1761 on the ship Hopewell.

Caucasian (2-6), African-American (6, 8-10), and Australian aboriginal (11) families have been described with this disease. The NDI locus was mapped to the distal region of the long arm of the X-chromosome (Xq28) by linkage analysis ( 3 , $6,12,13)$. van den Ouweland et al. (14) reported that the NDI locus maps close to the color-vision pigment genes in Xq28 and have further localized the position between $D X S 52$ and $G 6 P D$ by using somatic cell hybrids. A candidate gene for NDI was the $V_{2}$ receptor on the basis of examining $V_{2}$ receptor binding activity and induction of cyclic-AMP production in response to vasopressin in somatic cell hybrids (15). The molecular cloning and characterization of the $\mathrm{V}_{2}$ receptor in the human (16) and rat (17) have recently been accomplished. The sequence of the cDNA predicts a polypeptide of 371 amino acids that has seven transmembrane, four extracellular, and four cytoplasmic domains $(16,18)$. The gene contains three exons and two small introns $(19,20)$. The identification of mutations in the $\mathrm{V}_{2}$ receptor gene (AVPR2) that segregate with NDI confirms the identification of the gene for NDI $(14,19$, $21,22)$.

We previously tested the Hopewell hypothesis by analysis of a four-locus haplotype of RFLPs and a VNTR in the Xq28 region (DXS305-DXS52-DXS15-F8C) and showed that affected males in three branches of the Hopewell pedigree shared the same haplotype (6). The NDI haplotype of the Hopewell kindred was not found in patients from other North American NDI families. Therefore, we concluded that the Hopewell hypothesis could not explain the origin of NDI in those North American families that have no apparent relationship to descendants of the Hopewell early settlers, either by haplotype or genealogical analysis. Here we describe the NDI mutation in the Hopewell kindred, as well as three other mutations in the AVPR2 gene, and a definitive test of the Hopewell hypothesis by mutation analysis.

\section{Methods}

Families. DNA was available from members of the Hopewell kindred and 12 other NDI families that we previously described (6). The Hopewell pedigree has been expanded (Fig. $1 a$ ) and blood samples were obtained from seven additional affected males and seven additional 

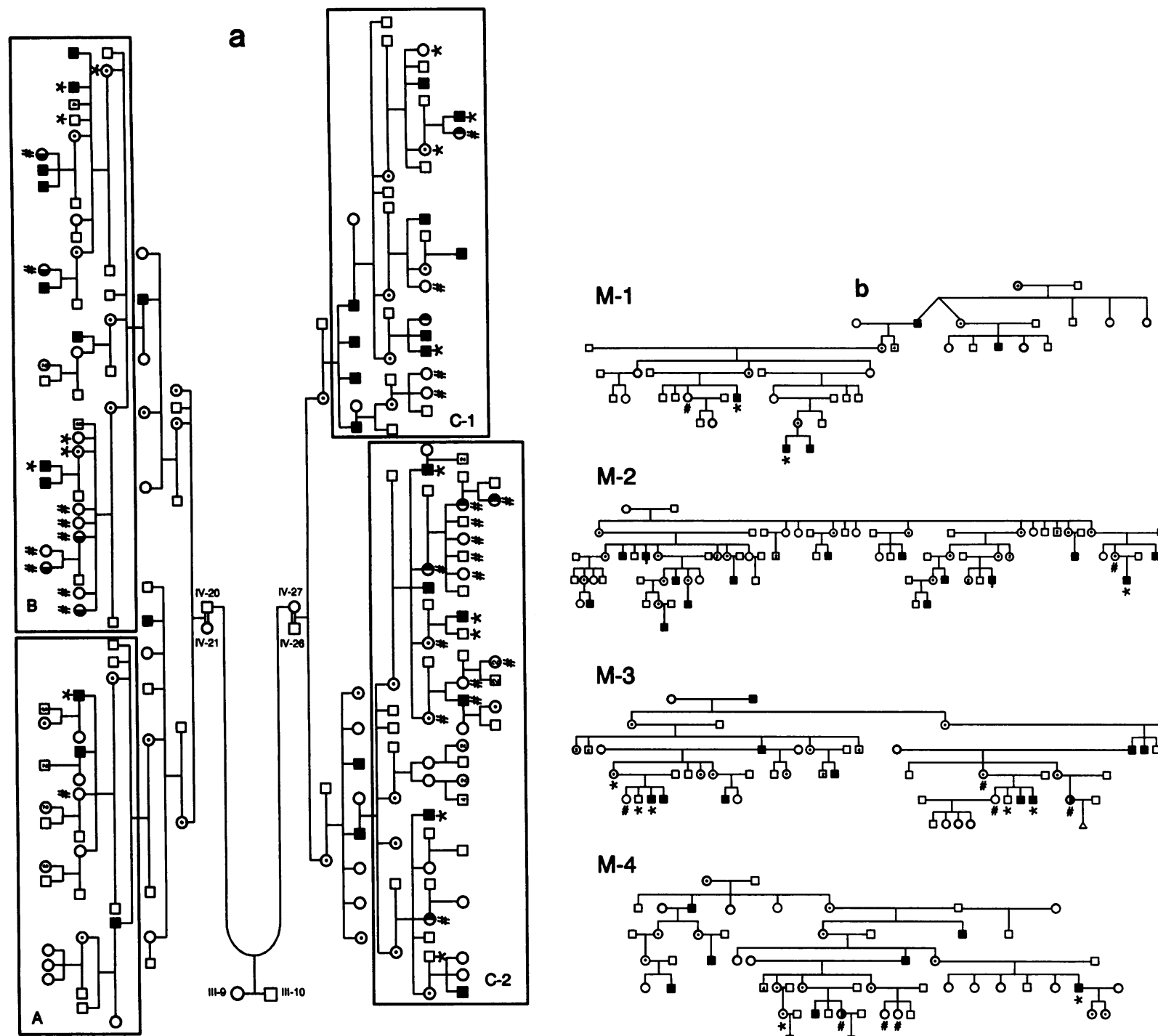

M-2
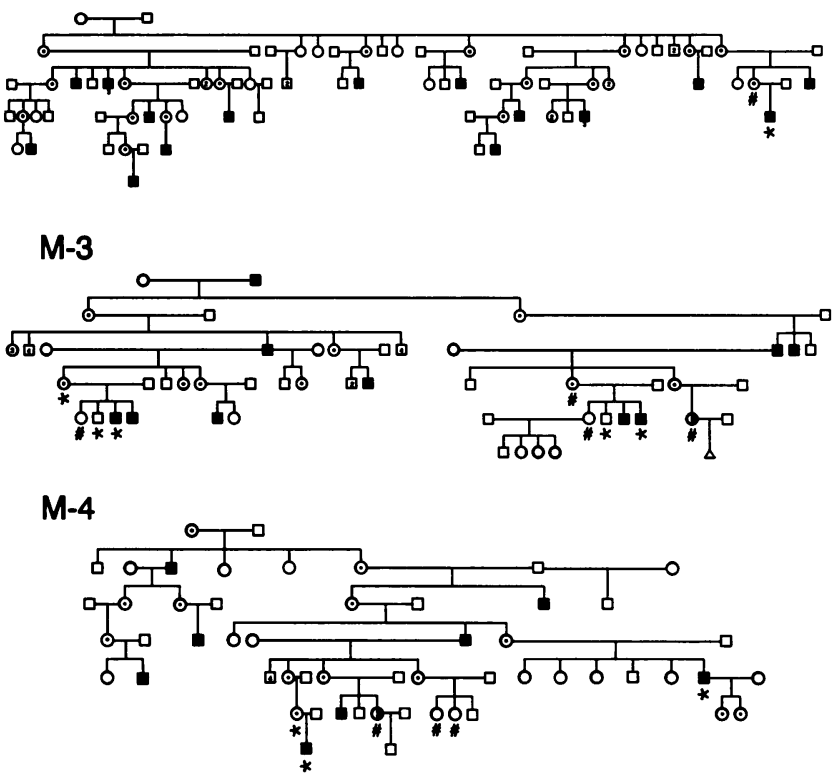

Figure 1. (a) Partial pedigree of the Hopewell kindred, which has been modified from Fig. 1 of Bichet et al. (6) and $(b)$ satellite pedigrees. $\star$ indicates DNA sequencing and ASO analyses; \# indicates mutation analysis by restriction enzyme digestion or ASO analyses. $\square$, unaffected male; -, affected male; $\odot$, obligate carrier female; and o, carrier female by DNA analysis; and $\circ$, noncarrier female by DNA analysis or unknown status if DNA was not available.

obligate carriers. Four additional extended families from Nova Scotia and New Brunswick were also studied (Fig. $1 b$ ). During our visits (D. G. Bichet, M.-F. Arthus, M. Lonergan) to Halifax over the last $4 \mathrm{yr}$, patients and/or physicians brought to our attention these additional NDI patients living in the Maritime area. These families (Maritime: $\mathbf{M}_{1}$ to $\mathrm{M}_{4}$ ) have Scottish ancestry and are not known to be related to each other or to the Hopewell kindred. For one family $\left(\mathbf{M}_{\mathbf{2}}\right)$ we were able to establish ancestry antedating the arrival of the ship Hopewell in 1761, but we were unable to link the ancestors to the original Bode and Crawford pedigree. Specifically, all the names and ancestors of the Hopewell pedigree (generations I to IV) are known from our previous study (6); none of these ancestors were found in the $M_{2}$ pedigree. Family $M_{4}$ has been previously described (23). The phenotypic characteristics of the patients in families $\mathbf{M}_{\mathbf{2}}$ through $\mathbf{M}_{\mathbf{4}}$ were similar to those we previously described $(24,25)$. In addition, five other unpublished pedigrees of $\mathrm{X}$-linked NDI families were also studied.

Haplotype analysis. RFLP analysis of the probe/enzyme (and locus) combinations, St35-691/TaqI (DXS305), DX13/BglII (DXS15), and F814/BclI $(F 8 C)$, and PCR analysis of the St 14 VNTR (DXS52) were done as previously described (6).
DNA sequencing. Genomic DNA was prepared from whole blood as previously described (6). The AVPR2 gene was first amplified by nested PCR (Fig. 2), with a PCR system (GeneAmp model 9600; Perkin Elmer Cetus Ltd., Montréal, P.Q., Canada). A general amplification protocol was done in a final volume of $50 \mu \mathrm{l}$ : initial denaturation at $98^{\circ} \mathrm{C}$ for $5 \mathrm{~min}$, addition of $\mathrm{Taq}$ polymerase $(2 \mathrm{U} /$ tube; Perkin Elmer Cetus Ltd.) denaturation at $94^{\circ} \mathrm{C}$ for $2 \mathrm{~min}$, and 30 cycles, each consisting of denaturation at $94^{\circ} \mathrm{C}$ for $10 \mathrm{~s}$, annealing at $62^{\circ} \mathrm{C}$ for $15 \mathrm{~s}$, and elongation at $72^{\circ} \mathrm{C}$ for $60 \mathrm{~s}$ and a final extension at $72^{\circ} \mathrm{C}$ for $10 \mathrm{~min}$. The first PCR was done with 0.5 to $1 \mu \mathrm{g}$ of genomic DNA using primers 58 and 2 (Fig. 2), and the second ("nested") PCR with $3.5 \mu$ l of the first PCR product using primers 62 and 63 . The final $2-k b$ PCR product was amplified either by two different asymmetric PCRs using primers 64 and 65 , or by subcloning into Bluescript KS (Stratagene Inc., La Jolla, $\mathrm{CA}$ ) as previously described (21). Sequencing of $\sim 0.5 \mu \mathrm{g}$ of singlestrand DNA (obtained by asymmetric PCR) or of $\sim 3 \mu \mathrm{g}$ of doublestranded DNA (by cloning) was done using the dideoxy chain termination method with the Sequenase kit (version 2.0; United States Biochemical Corp., Cleveland, $\mathrm{OH}$ ). A total of 12 different primers (sense and antisense) covering the entire AVPR2 gene were needed for se- 

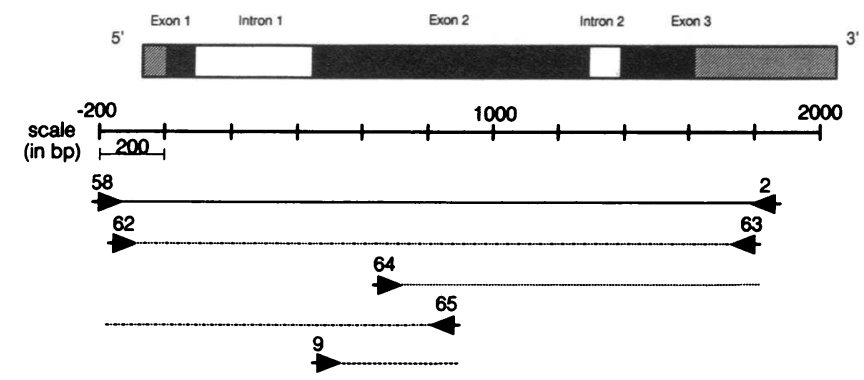

\begin{tabular}{|c|c|c|c|}
\hline No. & Description & Orientation & Corresponding V2 receptor gene sequence \\
\hline 58 & 5'-TGAССАТСССТСТСААТСТTC-3' & sense & $-203 \longrightarrow-183$ \\
\hline 2 & 5'-TCССTCTITCCTGCСАCTCCT-3' & antisense & $+1858 \longleftarrow+1878$ \\
\hline 62 & 5'-CAGTTTGGATCCCCAGGACTGGCCATACTG-3' & sense & $\begin{array}{l}\text { Bamt l site CAGTTGGATC } \\
\text { followed by }-178 \longrightarrow-160\end{array}$ \\
\hline 63 & 5'-CAGTTIGGATCCCAGCTCAGTGAGCTGAC-3' & antisense & $\begin{array}{l}\text { Bamill site CAGTTGGGATC } \\
\text { followed by }+1812 \stackrel{1830}{\longleftarrow}\end{array}$ \\
\hline 65 & 5'-CGCTGGGCGAAGATGAAGAGCT-3' & antisense & $+882 \longleftarrow+903$ \\
\hline 64 & 5'-TGGAAGGCCACCGACCGCTT-3' & sense & $+656 \longrightarrow+675$ \\
\hline 9 & 5'-CGGAGCTGGCGCTGCTC-3' & senses & $+476 \longrightarrow+493$ \\
\hline
\end{tabular}

Figure 2. Schematic diagram showing the exon/intron organization of the AVPR2 gene. Exons are represented by either a shaded box (untranslated region) or a solid box (protein coding region), and introns by an open box (20). The nested primers that amplify a 2007-bp fragment containing the entire AVPR2 gene are shown below the map. Primers (and their sequences) used to amplify fragments to detect mutations are also shown.

quencing (sequences available from M. Birnbaumer or D. G. Bichet). For each family at least one affected male and one obligate carrier were sequenced in addition to, where possible, at least one unaffected brother of a patient.

Restriction enzyme and allele specific oligonucleotide (ASO) analyses. A nested PCR was done from 0.5 to $1 \mu \mathrm{g}$ of genomic DNA with primers 2 and 58, followed by primers 9 and 65 (Fig. 2), giving a final amplified product of $427 \mathrm{bp}$. After incubation with BsiHKAI (isoschizomer of $\mathrm{HgiAI}, 1 \mathrm{~h}$ at $\left.60^{\circ} \mathrm{C}, 10 \mathrm{U} / 10 \mu \mathrm{l}\right)$, Ddel $\left(1 \mathrm{~h}\right.$ at $37^{\circ} \mathrm{C}, 10$ $\mathrm{U} / 10 \mu \mathrm{l})$ or BsrI $\left(1 \mathrm{~h}\right.$ at $\left.65^{\circ} \mathrm{C}, 4 \mathrm{U} / 10 \mu \mathrm{l}\right)$, digestion products were analyzed by electrophoresis on $1 \%$ agarose (Sigma Chemical Co. St. Louis, MO) gel (TAE buffer, pH 8.0) with a 1-kb DNA ladder (GibcoBRL Ltd., Burlington, Ont., Canada) as a DNA size marker. Restriction enzymes were purchased from New England Biolabs Ltd., Mississauga, Ont., Canada.

For the ASO analysis, the PCR-amplified genomic DNA of the AVPR2 gene was blotted on nylon membranes (Zeta-Probe; Bio-Rad Laboratories, Richmond, CA) and hybridized with ${ }^{32}$ P-labeled 16-mer allele specific oligonucleotides (normal and mutant sequences) in $5 \times$ SSPE, $0.5 \%$ SDS, and $5 \times$ Denhardt's reagent at $48^{\circ} \mathrm{C}$ (normal sequence) or $46^{\circ} \mathrm{C}$ (mutant sequence) for $1 \mathrm{~h}$. The membranes were then washed in $2 \times \mathrm{SSPE}$ and $0.1 \%$ SDS at $52^{\circ} \mathrm{C}$ (normal sequence) or $50^{\circ} \mathrm{C}$ (mutant sequence) for $10 \mathrm{~min}$. The film was exposed to the membrane with an intensifying screen at $-80^{\circ} \mathrm{C}$ for 2 to $4 \mathrm{~h}$.

\section{Results}

Affected males of the Hopewell kindred carry the Xq28 (DXS305-DXS52-DXS15-F8C) haplotype 1-5-1-2 (6). We found this same haplotype in the four Maritime families in each of which at least one affected male was tested.

Sequencing analysis of the AVPR2 gene in the Hopewell family identified a G-to-A transition at nucleotide position 284 (sequence numbering according to the GenBank entry Z11687 [17]). The same mutation was present in affected patients of the Maritime families. These Maritime families are thus likely related to the Hopewell family and we call them "satellite" families. The nonsense mutation, $\mathrm{W} 71 \mathrm{X}$, which we will call the "Hopewell" mutation, leads to a predicted change of tryptophan (codon 71, TGG) to a stop codon (TGA) (Fig. 3). The predicted protein truncated at codon 71 would lack six transmembrane domains, three extracellular domains, and three cytoplasmic domains (Fig. 4). The W71X mutation was found in the DNA of all patients and obligate carriers studied (Fig. 1) and not in the DNA of unaffected males.

The G-to-A transition of the W71X mutation creates a $\mathrm{HgiAI}$ as well as a DdeI restriction site. Results presented in Fig. 5 were done with BsiHKAI (isoschizomer of HgiAI), but similar data were obtained with DdeI. The W71X mutation also abolishes two restriction sites, those for NlaIV and BsrI. Only BsrI was tested on some individuals. Unaffected males were found to have the two predicted fragments ( 255 and 99 bp). Affected males had only one 354-bp product and carriers had the three fragments (there is a constant 73-bp band, data not shown).

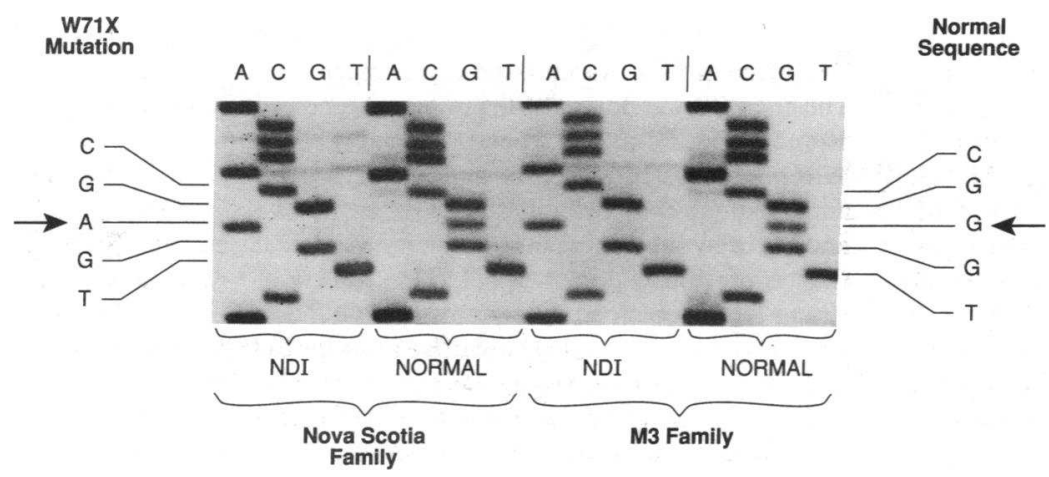

Figure 3. DNA sequence analysis of the Hopewell mutation, W71X. The arrows indicate the nucleotide change, G-to-A, which results in a substitution of a stop codon for tryptophan at AVPR2 residue 71. 


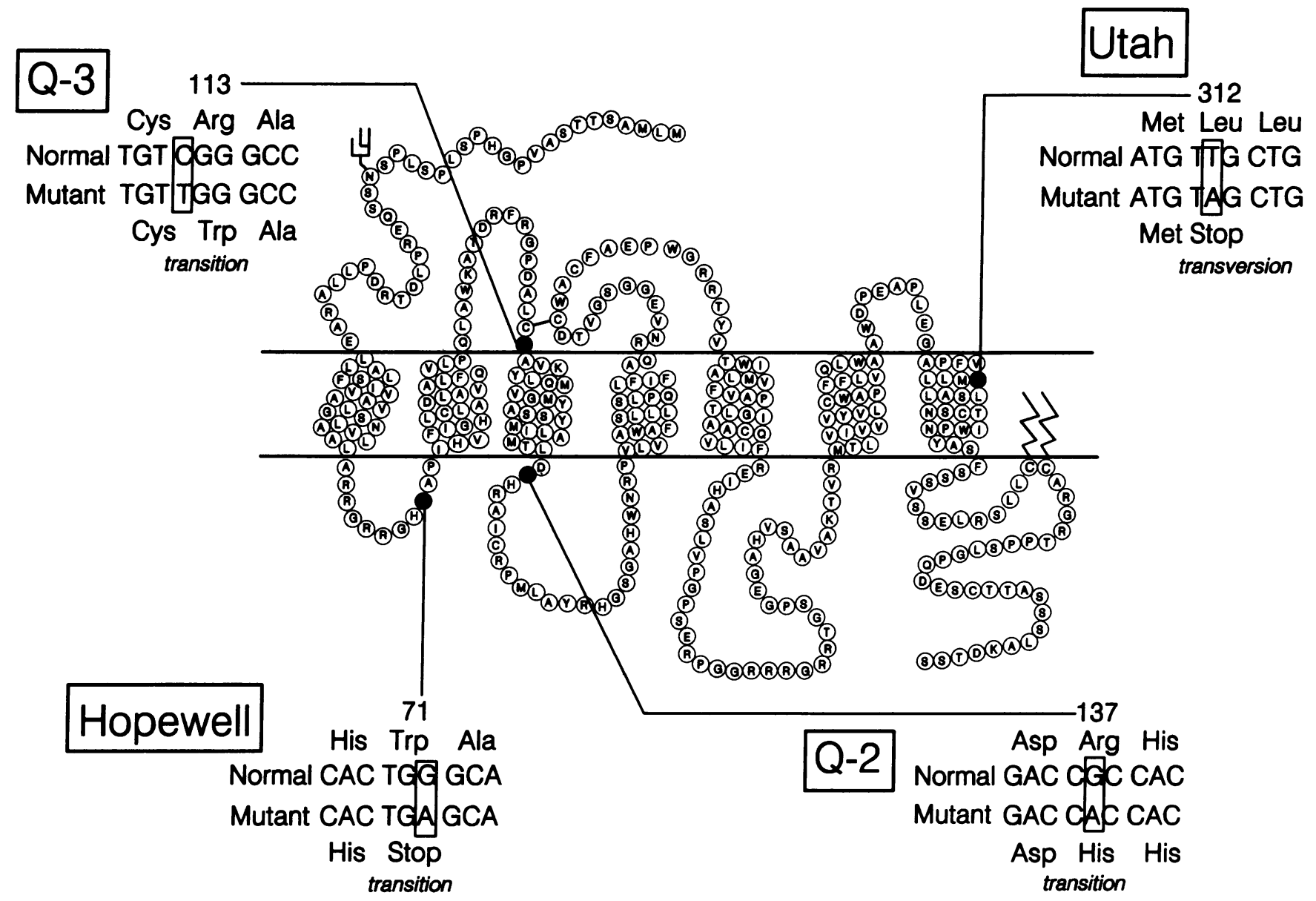

Figure 4. Schematic representation of the $\mathrm{V}_{2}$ receptor and identification of AVPR2 mutations in the $\mathrm{Q}_{2}, \mathrm{Q}_{3}$, Utah, and Hopewell families.

ASO analysis was also used to test for the presence of the W71 X mutation in affected patients and carriers. The normal sequence was found in both normal males and carriers, and the mutation was detected in patients and female carriers (Fig. 5).

The W71X mutation was not found either by sequencing or by restriction enzyme analysis in the 12 other families we previously described (6), nor in five other unpublished X-linked
NDI families recently referred to us (these latter five families have the following origins: French-Canadian, North-American Caucasian, Italian, Vietnamese, and African from the Congo).

Three other mutations (Fig. 4) were identified by sequencing analysis in the $Q_{2}, Q_{3}$, and the Utah families (6). The mutation identified in family $\mathrm{Q}_{3}$ is a C-to- $T$ transition at nucleotide position 408 that leads to a predicted change of argi-

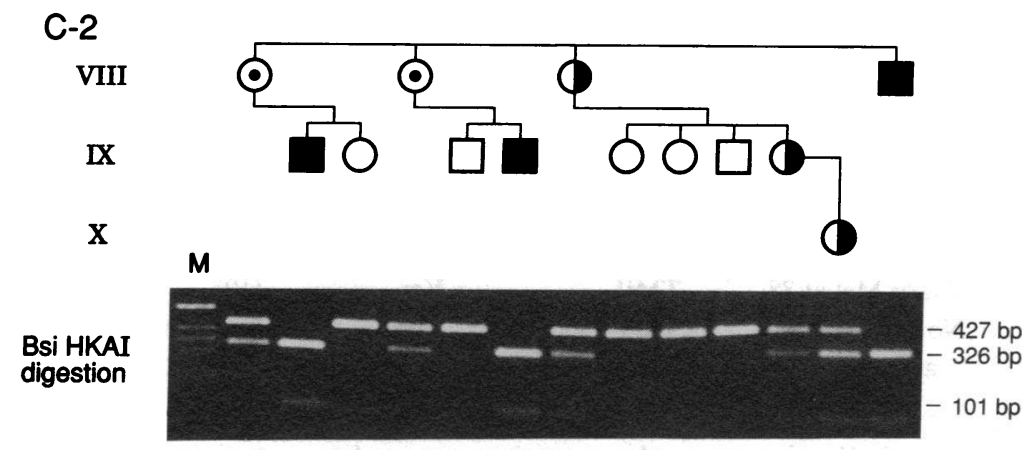

Normal ASO

Mutant ASO
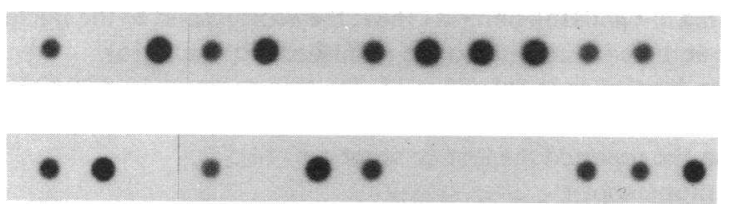

Figure 5. Partial pedigree of a family from the Hopewell kindred. Mutation analysis of PCR amplified genomic DNA by $(a)$ BsiHKAI digestion: DNA of genotypically normal individuals gives one fragment (427 bp); DNA of affected males yields two fragments ( 326 and $101 \mathrm{bp}$ ) and DNA of female carriers yields three fragments $(427,326$, and $101 \mathrm{bp})$; and $(b)$ ASO analysis: hybridization of mutant (5'-CCACTGAGCACCCATA-3') and normal (5'-CCACTGGGCACCCATA-3') oligonucleotide sequences to a 2007-bp fragment containing the entire AVPR2 gene. 
nine (codon 113, CGG) to tryptophan (TGG) (R113W). Another missense mutation was identified in family $Q_{2}$, it is a G-to-A transition at nucleotide position 481 and leads to a predicted change of arginine (codon 137, CGC) to histidine (CAC) $(\mathrm{R} 137 \mathrm{H})$. A nonsense mutation was identified in the Utah kindred; it is a T-to-A transversion at nucleotide position 1006 and leads to a predicted change of leucine (codon 312 , TTG) to a stop codon (TAG) (L312X). The R113W and $\mathrm{R} 137 \mathrm{H}$ missense mutations, both of which are in exon 2, alter the coding for amino acid residues predicted to be in the second extracellular domain and the second cytoplasmic domain, respectively. The L312X mutation is in exon 3 , which is pre- dicted to encode the seventh transmembrane domain and the fourth cytoplasmic domain.

\section{Discussion}

The Hopewell hypothesis. X-linked nephrogenic diabetes insipidus is a well-known disease in Nova Scotia and New Brunswick, with a prevalence of 24/1,000 males in certain well-defined communities. By contrast, the prevalence of NDI in the province of Quebec is only about 4/1,000,000 males (6).

On the basis of genealogical data on NDI families, Bode and Crawford proposed a common origin of all North Ameri-

Table I. NDI Mutations and Sequence Variations in the $V_{2}$ Receptor Gene (AVPR2)

\begin{tabular}{|c|c|c|c|c|c|c|}
\hline Name* & $\begin{array}{l}\text { Type of } \\
\text { mutation }\end{array}$ & $\begin{array}{l}\text { Nucleotide } \\
\text { change }^{\ddagger}\end{array}$ & $\begin{array}{l}\text { Predicted amino acid } \\
\text { change }^{\ddagger}\end{array}$ & $\begin{array}{l}\text { Location in } \\
\text { predicted } \\
\text { protein } \\
\text { structure }\end{array}$ & $\begin{array}{l}\text { Amino acid } \\
\text { conserved in } \\
\text { rat } V_{2} \\
\text { receptor (17) }\end{array}$ & $\begin{array}{l}\text { (Reference) } \\
\text { family/patient }\end{array}$ \\
\hline \multicolumn{7}{|c|}{ Mutations causing NDI } \\
\hline W71X & Nonsense & $\mathrm{G} \rightarrow \mathrm{A}$ at 284 & $\operatorname{Trp} \rightarrow$ stop at 71 & $\mathrm{CI}$ & Yes & $\begin{array}{l}\text { (This study) Hopewell } \\
\text { kindred }\end{array}$ \\
\hline R113W & Missense & $\mathrm{C} \rightarrow \mathrm{T}$ at 408 & Arg $\rightarrow$ Trp at 113 & EII & Yes & (This study) Family $Q_{3}$ \\
\hline Q119X & Nonsense & $\mathrm{C} \rightarrow \mathrm{T}$ at 426 & Gln $\rightarrow$ stop at 119 & TMIII & Yes & (19) Patient 4 \\
\hline Y128S & Missense & $\mathrm{A} \rightarrow \mathrm{C}$ at 454 & Tyr $\rightarrow$ Ser at 128 & TMIII & Yes & (19) Patient 2 \\
\hline A132D & Missense & $C \rightarrow A$ at 466 & Ala $\rightarrow$ Asp at 132 & TMIII & Yes & (21) Family $O_{1}$ \\
\hline $\mathrm{R} 137 \mathrm{H}$ & Missense & $\mathrm{G} \rightarrow \mathrm{A}$ at 481 & Arg $\rightarrow$ His at 137 & CII & Yes & (This study) Family $Q_{2}$ \\
\hline (1) $\mathrm{R} 181 \mathrm{C}$ & (1) Missense & (1) $\mathrm{C} \rightarrow \mathrm{T}$ at 612 & $\begin{array}{l}\text { (1) Arg } \rightarrow \text { Cys at } \\
181\end{array}$ & (1) EIII & (1) Yes & (19) Patient 5 \\
\hline (2) 810 del 12 & $\begin{array}{l}\text { (2) Inframe } \\
\text { deletion }\end{array}$ & $\begin{array}{l}\text { (2) Deletion of } \\
12 \mathrm{bp} 3^{\prime} \text { to } 810\end{array}$ & $\begin{array}{l}\text { (2) Deletion of } \\
\text { Arg247-Arg248- } \\
\text { Arg249-Gly250 }\end{array}$ & (2) CIII & (2) No & \\
\hline G185C & Missense & $\mathrm{G} \rightarrow \mathrm{T}$ at 624 & Gly $\rightarrow$ Cys at 185 & EIII & No & (14) Patient 128 \\
\hline R202Cll & Missense & $\mathrm{C} \rightarrow \mathrm{T}$ at 675 & Arg $\rightarrow$ Cys at 202 & EIII & No & (14) Patient 350 \\
\hline Y205C & Missense & $A \rightarrow G$ at 685 & Tyr $\rightarrow$ Cys at 205 & EIII & Yes & (14) Patient 134 \\
\hline 753insC & Frameshift & $\begin{array}{l}\text { Insertion of } \mathrm{C} \text { in } \\
\text { codon } 228 \\
\text { (nucleotide } \\
754 \text { ) }\end{array}$ & $\begin{array}{l}\text { Frameshift } 3^{\prime} \text { to } \\
\text { codon } 228 ; \\
\text { codon } 258 \rightarrow \\
\text { stop }\end{array}$ & $\begin{array}{l}\text { TMV and } \\
\text { CIII }\end{array}$ & Yes & (30) \\
\hline 763delA & Frameshift & $\begin{array}{l}\text { Deletion of A at } \\
763\end{array}$ & $\begin{array}{l}\text { Frameshift } 3^{\prime} \text { to } \\
\text { codon } 231 ; \\
\text { codon } 270 \rightarrow \\
\text { stop }\end{array}$ & CIII & Yes & (19) Patient 3 \\
\hline 804delG & Frameshift & $\begin{array}{l}\text { Deletion of } G \\
\text { between } 804- \\
809\end{array}$ & $\begin{array}{l}\text { Frameshift } 3^{\prime} \text { to } \\
\text { codon } 247 ; \\
\text { codon } 270 \rightarrow \\
\text { stop }\end{array}$ & CIII & No & (21) Family $Q_{5}$ \\
\hline P286R & Missense & $\mathrm{C} \rightarrow \mathrm{G}$ at 928 & Pro $\rightarrow$ Arg at 286 & TMVI & Yes & (19) Patient 6 \\
\hline L312X & Nonsense & $\mathrm{T} \rightarrow \mathrm{A}$ at 1006 & Leu $\rightarrow$ stop at 312 & TMVII & Yes & $\begin{array}{l}\text { (This study) Utah } \\
\text { family }\end{array}$ \\
\hline \multicolumn{7}{|c|}{ Sequence variations not causing NDI } \\
\hline $333(G \text { or } A)^{n}$ & Missense & G or $A$ at 333 & Val or Met at 88 & TMII & Yes & (19) \\
\hline $998(A$ or $G)$ & $\begin{array}{l}\text { Silent } \\
\quad \text { substitution }\end{array}$ & A or $\mathrm{G}$ at 998 & $\begin{array}{l}\text { No change (Leu) } \\
\text { at } 309\end{array}$ & TMVII & Yes & (21) Family $Q_{5}$; (19) \\
\hline
\end{tabular}

\footnotetext{
* The names were assigned following the nomenclature used for cystic fibrosis transmembrane conductance regulator mutations (26).

‡ The nucleotides are numbered according to the sequence numbering of GenBank entry Z11687; they correspond to the nucleotide position plus 71 bases presented in Fig. 1 of reference 16. The amino acids are numbered according to the published sequence (16).

${ }^{8}$ The extracellular (EI-EIV) and cytoplasmic domains (CI-CIV) are labeled as in reference 18; the transmembrane domains are labeled TMITMVII.

"The amino acid position has been assigned to codon 202 based on the reported nucleotide sequence (14).

"The amino acid position is codon 88 (Gitschier, J., personal communication).
} 
can families affected with NDI (4). A link between the Hopewell pedigree and Cannon's large Utah kindred was also suggested, based on the similarity of some surnames among the ancestors in the two pedigrees. The cloning of the AVPR2 gene and the identification of mutations that cause NDI allowed us to definitively test the hypothesis that Bode and Crawford doubted could ever be proved. The W71X mutation was found only in the Hopewell and satellite families. This is consistent with our previous haplotype analysis (6) and new haplotype data on the satellite families that show that all affected males tested in the Hopewell and satellite families share the same Xq28 haplotype 1-5-1-2. The four other North American families $\left(Q_{2}, Q_{3}, Q_{5}\right.$, and the Utah family) with identified mutations, each carry different mutations on different haplotypes. The members of the Hopewell and satellite families comprise the largest number of related male patients with X-linked NDI and living in North America. The fact that family $\mathbf{M}_{2}$ and the Hopewell kindred share the same mutation, despite the fact that they do not share known common ancestors, underscores the fact that the $\mathrm{W} 71 \mathrm{X}$ mutation is not restricted to the pedigree published by Bode and Crawford. In accordance with our previous suggestion (6), these results confirm that carriers of the "Hopewell" mutation were prevalent in the Maritime area at the time of the landing of the ship Hopewell. Therefore, we anticipate that other NDI families, not known to be related to the Hopewell kindred, will be found carrying the W71X mutation.

Carrier detection. It is now possible to evaluate families with X-linked NDI by mutation analysis and/or haplotype analysis. In our studies there was a complete association between the W71X mutation and St14 VNTR (6). Our procedure is to first analyze the segregation of haplotypes by PCR analysis of the St14 VNTR. This is followed by HgiAI restriction enzyme analysis in families carrying the 1630-bp St14 VNTR allele. In other families, complete sequencing of the AVPR2 gene is done. In informative NDI families in which the mutation has not yet been identified, segregation of the St14 VNTR can be used for carrier detection (6). Early diagnosis and treatment of male infants affected with NDI can avert the physical and mental retardation that are the consequences of episodes of dehydration.

The $V_{2}$ receptor mutation repertoire. 16 mutations have now been reported (Table I). The majority of the mutations are clustered within the third extracellular loop, the third transmembrane domain, or the third intracellular loop (22), which have previously been shown to be important for various functions, such as ligand binding and effector coupling, for other seven-membrane spanning receptors $(27,28)$. However, the W71X and L312X mutations lie outside these functionally important regions. This emphasizes that study of these naturally occurring mutations will be extremely helpful in pinpointing additional critical functional regions of the molecule. Truncated receptors generated by nonsense mutations like the W71X and the L312X mutations will be nonfunctional (Fig. 4 ), as expected from results obtained with the adrenergic receptor (29). Missense mutations could cause misfolding of the protein and trapping into the endoplasmic reticulum, or could alter formation of the binding pocket or the contact surface that activates $G_{\mathbf{s}}$. For example, missense mutations causing alterations in the region of the disulphide bridge joining extracellular loops II and III (analogous to the R113W mutation in family $Q_{3}$ ) might alter the proper folding and the transmem- brane assembly of the $V_{2}$ receptor. The $Q_{2}$ mutant receptor with an alteration in intracellular loop II may be unable to interact properly with the GTP-binding protein. However, all mutant receptors will need to be expressed in terms of in vitro experimental systems to determine how specific alterations influence ligand binding or affect signal transduction.

Genotype-phenotype correlations. In all the families tested, we have not been able to identify phenotypic differences for the following end points: number and severity of dehydration episodes during infancy with consequent mental retardation; maximal urinary osmolality achieved during dehydration with a plasma sodium between 147 and $153 \mathrm{mmol} /$ liter; plasma arginine-vasopressin concentrations; and absence of hemodynamic and coagulation responses to dDAVP infusions (24, 25). Patients with the mutations described here and by Rosenthal et al. (21) appear to have a uniform phenotype.

In summary, the sequencing of the $V_{2}$ receptor gene and mutation analysis of the Hopewell, Utah, and two French-Canadian NDI families have demonstrated the independent origin of NDI among these families. The W71X mutation was identified in 64 individuals, the largest known number of NDI patients and carriers in North America who share a $V_{2}$ receptor mutation identical by descent. Carrier detection and early diagnosis of affected male infants are proposed.

\section{Acknowledgments}

We thank the patients and their families for their participation, and Nicole Ruel and Nancy O'Neil for technical assistance. We thank Drs. Georges Bashali, Michael S. Brown, John F. S. Crocker, Julien d'Astous, Jessica G. Davis, Joe Gertner, Philip Giampietro, Paul Goodyer, Mitch Halperin, David Hirsch, Nicola Laforgia, Julian Midgely, Labkir Nayak, Sonia Salisbury, Simonetta Simonetti, and Karl Skorecki for referring their patients to us. We thank Mr. Jean-Pierre Boisvert, Merck Frosst Canada, and Dr. Charles Scriver, McGill University, for their encouragement of our studies.

This work was supported by grants from the Medical Research Council of Canada (MT-8126 and MA-9315), the Canadian Kidney Foundation, the Canadian Genetic Diseases Network, and Merck Frosst Canada. Dr. W. Rosenthal, Aarati Didwania, Anaid Antaramian, and Dr. M. Birnbaumer (grantee) were supported by National Institutes of Health grant DK-41244. Dr. W. Rosenthal is a recipient of a Heisenberg Fellowship from the Deutsche Forschungsgemeinschaft. Dr. D. Bichet and Dr. G. N. Hendy are senior scholars of Le Fonds de la Recherche en Santé du Québec.

\section{References}

1. McKusick, V. A. 1990. Mendelian Inheritance in Man. 9th ed. The Johns Hopkins University Press, Baltimore. 1585.

2. Forssman, H. 1975. Modern medical history. The recognition of nephrogenic diabetes insipidus. Acta. Med. Scand. 197:1-6.

3. Knoers, N., H. van der Heyden, B. A. van Oost, L. Monnens, J. Willems, and H. H. Ropers. 1989. Three-point linkage analysis using multiple DNA polymorphic markers in families with X-linked nephrogenic diabetes insipidus. Genomics. 4:434-437.

4. Bode, H. H., and J. D. Crawford. 1969. Nephrogenic diabetes insipidus in North America. The Hopewell hypothesis. N. Engl. J. Med. 280:750-754.

5. Cannon, J. F. 1955. Diabetes insipidus: clinical and experimental studies with consideration of genetic relationships. Arch. Intern. Med. 98:215-272.

6. Bichet, D. G., G. N. Hendy, M. Lonergan M., M. F. Arthus, S. Ligier, Z. Pausova, R. Kluge, H. Zingg, P. Saenger, E. Oppenheimer et al. 1992. X-linked nephrogenic diabetes insipidus: from the ship Hopewell to RFLP studies. Am.J. Hum. Genet. 51:1089-1102.

7. Reeves, W. B., and T. E. Andreoli. 1989. Nephrogenic diabetes insipidus In The Metabolic Basis of Inherited Disease. 6th ed. C. R. Scriver, A. L. Beaudet, W. S. Sly, and D. Valle, editors. McGraw-Hill, New York. 1985-2011. 
8. Bianchine, J. W., A. A. Stambler, and H. E. Harrison. 1971. Nephrogenic (vasopressin-resistant) diabetes insipidus with the usual $\mathrm{X}$-linked inheritance. Birth Defects Orig. Artic. Ser. 7:280-281.

9. Feigin, R. D., D. L. Rimoin, and R. L. Kaufman. 1970. Nephrogenic diabetes insipidus in a Negro kindred. Am. J. Dis. Child. 120:64-68.

10. Libber, S., H. Harrison, and D. Spector. 1986. Treatment of nephrogenic diabetes insipidus with prostaglandin synthesis inhibitors. J. Pediatr. 108:305311.

11. Schultz, P., and D. R. Lines. 1975. Nephrogenic diabetes insipidus in an Australian aboriginal kindred. Humangenetik. 26:79-85.

12. Kambouris, M., S. R. Dlouhy, J. A. Trofatter, P. M. Conneally, and M. E. Hodes. 1988. Localization of the gene for X-linked nephrogenic diabetes insipidus to Xq28. Am. J. Med. Genet. 29:239-246.

13. van den Ouweland, A. M. W., M. T. Knoop, N. V. A. M. Knoers, P. W. B Markslag, M. Rocchi, S. T. Warren, H. H. Ropers, F. Fahrenholz, L. A. H. Monnens, and B. A. van Oost. 1992. Colocalization of the gene for nephrogenic diabetes insipidus (DIR) and the vasopressin type 2 receptor gene (AVPR2) in the Xq28 region. Genomics. 13:1350-1352.

14. van den Ouweland, A. M. W., J. C. F. M. Dreesen, M. Verdijk N. V. A. M. Knoers, L. A. H. Monnens, M. Rocchi, and B. A. van Oost. 1992. Mutations in the vasopressin type 2 receptor gene (AVPR2) associated with nephrogenic diabetes insipidus. Nature Genet. 2:99-102.

15. Jans, D. A., B. A. van Oost, H. H. Ropers, and F. Fahrenholz. 1990. Derivatives of somatic cell hybrids which carry the human gene locus for nephrogenic diabetes insipidus (NDI) express functional vasopressin renal $\mathrm{V}_{2}$-type receptors. J. Biol. Chem. 265:15379-15382.

16. Birnbaumer, M., A. Seibold, S. Gilbert S., M. Ishido, C. Barberis, A. Antaramian, P. Brabet, and W. Rosenthal. 1992. Molecular cloning of the receptor for human antidiuretic hormone. Nature (Lond.). 357:333-335.

17. Lolait, S. J., A. M. O'Carroll, O. W. McBride, M. Konig, A. Morel, and M. J. Brownstein. 1992. Cloning and characterization of a vasopressin $V_{2}$ receptor and possible link to nephrogenic diabetes insipidus. Nature (Lond.). 357:336339.

18. Sharif, M., and M. R. Hanley. 1992. Stepping up the pressure. Nature (Lond.). 357:279-280.

19. Pan, Y., A. Metzenberg, S. Das, B. Jing, and J. Gitschier. 1992. Mutations in the V2 vasopressin receptor gene are associated with $\mathrm{X}$-linked nephrogenic diabetes insipidus. Nature Genet. 2:103-106.

20. Seibold, A., P. Brabet, W. Rosenthal, and M. Birnbaumer. 1992. Structure and chromosomal localization of the human antidiuretic hormone receptor gene. Am. J. Hum. Genet. 51:1078-1083.

21. Rosenthal, W., A. Seibold, A. Antaramian, M. Lonergan, M. F. Arthus, G. N. Hendy, M. Birnbaumer, and D. G. Bichet. 1992. Molecular identification of the gene responsible for congenital nephrogenic diabetes insipidus. Nature (Lond.). 359:233-235.

22. Davies, K. 1992. Diabetes defect defined. Nature (Lond.). 359:434

23. Walker, N. F., and C. P. Rance. 1954. Inheritance of nephrogenic diabetes insipidus. Am. J. Hum. Genet. 6:354-358.

24. Bichet, D. G., M. Razi, M. Lonergan, M. F. Arthus, V. Papukna, C. Kortas, and J. N. Barjon. 1988. Hemodynamic and coagulation responses to 1-desamino [8-D-arginine] vasopressin in patients with congenital nephrogenic diabetes insipidus. $N$. Engl. J. Med. 318:881-887.

25. Bichet, D. G., M. Razi, M. F. Arthus, M. Lonergan, P. Tittley, R. D. Smiley, G. Rock, and D. J. Hirsch. 1989. Epinephrine and dDAVP administration in patients with congenital nephrogenic diabetes insipidus. Evidence for a pre-cyclic AMP $\mathrm{V}_{2}$ receptor defective mechanism. Kidney Int. 36:859-866.

26. Tsui, L. C. 1992. Mutations and sequence variations detected in the cystic fibrosis transmembrane conductance regulator (CFTR) gene: a report from the Cystic Fibrosis Genetic Analysis Consortium. Hum. Mutat. 1:197-203.

27. Savarese, T. M., and C. M. Fraser. 1992. In vitro mutagenesis and the search for structure-function relationships among $G$ protein-coupled receptors. Biochem. J. 283:1-19.

28. Ostrowski, J., M. A. Kjelsberg, M. G. Caron, and R. J. Lef kowitz. 1992. Mutagenesis of the $\beta_{2}$-adrenergic receptor: how structure elucidates function. Annu. Rev. Pharmacol. Toxicol. 32:167-183.

29. Kobilka, B. K., T. S. Kobilka, K. Daniel, J. W. Regan, M. G. Caron, and R. J. Lef kowitz. 1988. Chimeric $\alpha 2$-, $\beta 2$-adrenergic receptors: delineation of domains involved in effector coupling and ligand binding specificity. Science (Wash. DC). 240:1310-1316.

30. Merendino, J. J., A. M. Spiegel, J. D. Crawford, A. M. O’Carroll, M. J. Browstein, and S. J. Lolait. 1993. Brief report: a mutation in the vasopressin $\mathrm{V}_{2}$ receptor gene in a kindred with $\mathrm{X}$-linked nephrogenic diabetes insipidus. $N$. Engl. J. Med. 328:1538-1541. 